\title{
Higher Education in El Salvador: Pertinence and Education for Entrepreneurship
}

\author{
P. Pinazo-Dallenbach*, D.X. Tutistar-Rosero** \\ *ESIC Business and Marketing School \\ ** Universitat de Valencia
}

\begin{abstract}
The training of human resources is crucial for the economic and social development of territories that are striving to become knowledge-based economies. Although the number of student enrolments in El Salvador has increased in recent years, some elements of the higher education system have hindered the country's development from this approach. El Salvador's population is generally poorly qualified and particularly poorly specialized. In addition, El Salvador has a low-quality higher education system, which employs poorly qualified teaching staff with outdated methods and syllabuses. The lack of pertinence of the higher education system in El Salvador is reflected in the conflict between the country's education and labour systems. This conflict has especially negative effects on younger generations' social mobility. To remedy this situation, this research presents proposals to improve the higher education system's pertinence and to implement a compulsory entrepreneurship education module across all areas of higher education.
\end{abstract}

Keywords: Higher education; El Salvador; Pertinence; Entrepreneurship; Qualifications

\section{Introduction}

Numerous studies have highlighted the benefits of knowledge-based economies in terms of the economic and social development of territories (Schramm, 2006; Audretsch, 2007; Levie \& Autio 2008). Nevertheless, most Latin American economies are in the efficiency-driven stage (López-Claros et al., 2006). These countries should therefore encourage innovation to reach the technological frontier and become knowledge-based economies - a characteristic of the innovation-driven stage (Porter et al., 2002). Wennekers et al. (2005) report that if policymakers in Latin America resign themselves to following natural tendencies without prioritizing entrepreneurship, they will merely reduce the rates of necessity-driven entrepreneurship without achieving higher growth in opportunity-driven entrepreneurship, which is based on innovation and value creation. Thus, policymakers should implement policies that foster innovative entrepreneurship to create new and improved firms with novel business models (Miles et al., 2005).

El Salvador falls into the aforementioned group of countries. As illustrated in the 2012 GEM Report (Sanchez-Masferrer, 2013), the quality of entrepreneurship in El Salvador fails to meet that of a knowledge-based economy. The rate of necessity-driven entrepreneurship is 35\%, far higher than the regional average, whereas opportunitydriven entrepreneurship - the driver of the creation and application of innovation - has a rate of just 39\%, which is lower than the regional average. These data imply that the entrepreneurial orientation in El Salvador is not conducive to innovation and projects offering high value added. The high abandonment rate among businesses $(7.9 \%$ - the highest in the region) compounds the weakness of El Salvador's entrepreneurial profile. 
Table 1. Entrepreneurship in El Salvador and the region (Latin America and the Caribbean)

\begin{tabular}{|l|c|c|c|}
\hline & $\begin{array}{c}\text { Necessity-driven } \\
\text { entrepreneurship }\end{array}$ & $\begin{array}{c}\text { Opportunity- } \\
\text { driven } \\
\text { entrepreneurship }\end{array}$ & $\begin{array}{c}\text { 12-month } \\
\text { abandon rate }\end{array}$ \\
\hline El Salvador & $35 \%$ & $39 \%$ & $7.9 \%$ \\
\hline Regional average & $22 \%$ & $51 \%$ & $5 \%$ \\
\hline
\end{tabular}

Source: Authors’ own work based on Sánchez-Masferrer (2013)

The large number of barriers to creating knowledge-based economies in Latin America hinders the creation of firms that fit the mould of the "entrepreneurial economy" (Amorós \& Cristi, 2008; Terjesen \& Amorós, 2010). The training of human resources, especially in the higher education system (Clark, 2004), is a pillar of this kind of economy. Nevertheless, despite massive efforts over the last 20 years in terms of democracy, property rights, and macroeconomic stability in the region, areas such as education and knowledge creation remain weak (Acs \& Amorós, 2008). An abundance of highly qualified workers would foster innovation-based entrepreneurship with high value added, which in the medium and long term would lead to the creation of new jobs for qualified candidates and would hence improve the sustainable human development of the territory. As reported by Alburquerque (2004), a country's education and training should meet the specific innovation needs of the local production systems. Offering a basic generalist education is not enough. Instead, the education system must meet the specific needs of the local production system (i.e., the available education must be relevant), and it must encourage creativity and new technology adoption.

The Ministry of Education (MINED) is the governing body of El Salvador's education system. Technical education and university education make up the higher education system, understood as systematic efforts in education and training after secondary education (Ley de Educación Superior de El Salvador. Cap. I, Art. 4). El Salvador has 7 technical institutes, 9 specialist higher education institutes, and 24 universities. The aim of these institutes is threefold: teaching, scientific research, and social outreach.

The limited resources assigned to education explain, in part, the education system's weak performance, particularly in terms of quality and pertinence. Despite advances in the last decade, public spending on education in relation to El Salvador's GDP is still low. According to the MINED's annual accounts, public spending on education rose from $3.44 \%$ of GDP (588.7 million USD) in 2005 to $3.93 \%$ of GDP (834.3 million USD) in 2010. According to country profiles published by the Information System on Educational Trends in Latin America (SITEAL, 2013), however, El Salvador performs poorly in comparison with other countries in the region. El Salvador's investment in percentage terms is lower than that of all neighbouring countries, except that of Guatemala, which invests $2.9 \%$ of its GDP. Excluding Panama, the country with the highest percentage spend is Honduras (7.6\%), followed by Costa Rica (5.9\%), both of which spend considerably more than El Salvador does.

By presenting a bibliographical analysis of public and private reports, this article characterizes El Salvador's higher education system. Analysis focuses on data relating to admissions, pertinence, and quality to identify major weaknesses that affect entrepreneurship and labour market integration by university graduates. This article proposes two actions to mitigate these weaknesses. The first proposal relates to improving the education system's pertinence. The second proposal, in contrast, relates to developing entrepreneurial aptitudes and attitudes of young university students in El 
Salvador. To do so, the proposal advocates the introduction of a compulsory module on education for entrepreneurship. Finally, conclusions and future research opportunities are presented.

\section{Data on admissions to higher education in El Salvador}

Crucially, El Salvador's labour force is generally poorly qualified. As shown by the Information System on Educational Trends in Latin America (SITEAL, 2013), just 18\% of El Salvador's population aged between 20 and 21 years enter higher education, of which only 53\% complete their studies. The following paragraphs summarize the main features of admissions to higher education in El Salvador.

In recent years, the number of higher education students in El Salvador has grown. According to the National Committee for Higher Education (Dirección Nacional de Educación Superior, 2014), in 2013 the number of students increased by 3.65\% with respect to 2012 levels. The same year, 176,063 students were enrolled in higher education. Of these students, 77,022 were men (46.5\%) and 88.597 were women (53.5\%). The enrolment rate was distributed across institutes as follows: 162,578 students (92.34\%) were enrolled in universities; 8,680 (4.93\%) were enrolled in specialist institutes; and 4,805 (2.73\%) were enrolled in technical institutes.

Around $86 \%$ of the higher education students were aged between 16 and 29 years. The most common age range was 19 to 23 years old. The population according to the Directorate-General of Statistics and Censuses (DIGESTYC) was 666,702 inhabitants, yielding a gross higher education admissions rate of $26.41 \%$. According to higher education institutions' records, for the same year, 86,934 students aged between 19 and 23 years enrolled in higher education, yielding a net higher education admissions rate of $13.04 \%$.

Despite improvements in recent years, however, general figures are too low, particularly those referring to postgraduates in specialist studies leading to $R \& D$, a pillar of knowledge-based economies. Only $3 \%$ of students enrolled in higher education were studying master's or PhD courses.

Table 2. Students enrolled in higher education in El Salvador by academic level and sex

\begin{tabular}{|l|c|c|c|}
\hline \multirow{2}{*}{ Academic level } & \multirow{2}{*}{ Total } & \multicolumn{2}{c|}{ By sex } \\
\cline { 3 - 4 } & & Male & Female \\
\hline Postgraduate (master's and PhD) & $3 \%$ & $48 \%$ & $52 \%$ \\
\hline Undergraduate (bachelor's) & $84 \%$ & $46 \%$ & $54 \%$ \\
\hline Technical student & $14 \%$ & $48 \%$ & $52 \%$ \\
\hline & $100 \%$ & $47 \%$ & $53 \%$ \\
\hline
\end{tabular}

Source: Authors’ own data using data from the National Committee for Higher Education (Dirección Nacional de Educación Superior, 2014)

\section{Pertinence and quality of higher education in El Salvador}

El Salvador's Ministry of Education defines 10 subject areas within professional training, each comprising degrees with similar characteristics: I) Art and Architecture; II) Economics, Management, and Business; III) Health; IV) Science; V) Agriculture and Environment; VI) Law; VII) Humanities; VIII) Technology; IX) Education; and $\mathrm{X})$ Social Sciences. The most popular subject area among El Salvador's students is Economics, Management, and Business (25.18\% of the student population). The second 
most popular area is Technology (19.79\%), and the third most popular area is Health (18.78\%).

Table 3. Percentage of enrolment by subject area and sex in El Salvador

\begin{tabular}{|c|c|c|c|}
\hline Subject area & Male & Female & $\begin{array}{c}\text { \% of students } \\
\text { enrolled }\end{array}$ \\
\hline $\begin{array}{c}\text { Economics, Management, and } \\
\text { Business }\end{array}$ & $42 \%$ & $58 \%$ & 25.18 \\
\hline Technology & $78 \%$ & $22 \%$ & 19.79 \\
\hline Health & $28 \%$ & $72 \%$ & 18.78 \\
\hline Law & $44 \%$ & $56 \%$ & 9.10 \\
\hline Education & $32 \%$ & $68 \%$ & 8.92 \\
\hline Humanities & $42 \%$ & $58 \%$ & 5.67 \\
\hline Social Sciences & $38 \%$ & $62 \%$ & 4.80 \\
\hline Art and Architecture & $53 \%$ & $47 \%$ & 4.17 \\
\hline Science & $45 \%$ & $55 \%$ & 1.82 \\
\hline Agriculture and Environment & $68 \%$ & $32 \%$ & 1.76 \\
\hline Total & $\mathbf{4 7 \%}$ & $\mathbf{5 3 \%}$ & $\mathbf{1 0 0}$ \\
\hline
\end{tabular}

Source: Authors' own data using data from the National Committee for Higher Education (Dirección Nacional de Educación Superior, 2014)

At the university level, the most popular degrees are the bachelor's degree in Business Management (8.58\% of the enrolled student population in 2013), the bachelor's degree in Law (7.50\%), and the bachelor's degree in marketing (5.44\%) (Dirección Nacional de Educación Superior, 2014). These three degrees cover more than $20 \%$ of total demand.

The excess of demand for these degrees shows that academic courses available in El Salvador's higher education system (UNDP, 2013) are of little pertinence. The regional needs of the labour market and of the country in general were not analysed before considering which academic courses to offer. Failure to consider these issues hinders the absorption of new graduates in the labour market and contributes to the devaluation of degree qualifications. These effects are consequences of the surplus of graduates enrolled in certain degrees, which depresses nominal wages. In addition, human resources are underused, and graduates from these degrees end up working in jobs where they are overqualified.

Another challenge facing El Salvador is the low quality of its education system in general, but in particular its higher education system. As reported by USAID (Sanders et al., 2012) in El Salvador: Higher education assessment and recommendations, a large number of the programmes use outdated syllabuses and fail to teach the right competencies to respond to market needs. Likewise, teachers lack qualifications - only 29.38\% have postgraduate studies and less than 2\% have PhDs (Dirección Nacional de Educación Superior, 2014). Furthermore, in many cases, teachers lack motivation and apply outdated pedagogical methods.

The poor quality of El Salvador's education system also devaluates national higher education qualifications. This devaluation triggers a cascade effect whereby firms hire university graduates when they need people with vocational training, people with vocational training when they need people with secondary school studies, and so forth. This cascade effect has arisen because the education system does not allow students to 
develop competencies in accordance with their level of education. Hence, firms hire overqualified candidates. Likewise, firms offer salaries in keeping with the qualification required of the position, which leads to a general reduction in graduates' nominal wages (UNDP, 2013).

In addition to the devaluation of degree qualifications and the reduction in nominal wages, unemployment is a major issue affecting higher education graduates. As highlighted by the UNDP (2013), people in unemployment in El Salvador have been in education on average one year longer than people in work have. This difference is greater among the younger population, which is better trained. Unemployed people aged between 16 and 25 years have been in education for 10 years on average, whereas employed people in this age range have been in education for just 8.8 years on average. This difference is even greater among unemployed and employed women in this age group (10.8 years and 9.5 years, respectively). In the 26-35 age group, differences between the unemployed and employed groups are similar to differences in the younger age group. Likewise, women are also more affected. Unemployed women aged 26 to 35 years have been in education for 11.7 years on average, whereas those in employment have been in education for just 9 years on average.

Table 4. Educational level of people in employment and unemployment in El Salvador in terms of average years in education

\begin{tabular}{|l|c|c|c|c|c|c|}
\hline & \multicolumn{3}{|c|}{ Employed } & \multicolumn{3}{c|}{ Unemployed } \\
\hline Age group & Men & Women & Total & Men & Women & Total \\
\hline $\mathbf{1 6 - 2 5}$ & 8.4 & 9.5 & 8.8 & 9.6 & 10.8 & 10.0 \\
\hline $\mathbf{2 6}-\mathbf{3 5}$ & 8.8 & 9.3 & 9.0 & 9.8 & 11.7 & 10.5 \\
\hline $\mathbf{3 6 - 4 5}$ & 7.9 & 8.0 & 8.0 & 6.8 & 11.1 & 8.1 \\
\hline $\mathbf{4 6 - 5 5}$ & 7.0 & 7.0 & 7.0 & 5.7 & 4.3 & 5.5 \\
\hline $\mathbf{5 6}$ or older & 4.7 & 4.0 & 4.4 & 3.4 & 1.0 & 3.3 \\
\hline Total & $\mathbf{7 . 6}$ & $\mathbf{7 . 9}$ & $\mathbf{7 . 8}$ & $\mathbf{8 . 0}$ & $\mathbf{1 0 . 7}$ & $\mathbf{8 . 8}$ \\
\hline
\end{tabular}

Source: Authors’ own data using data from the UNDP (2013)

The pattern described contradicts the assumption that better education and training lead to better work opportunities. Thus, not only are young people the worst affected, but also El Salvador's society as a whole views its opportunities for development as limited. This view demonstrates how El Salvador's human resources are being wasted in the quest for economic and social development.

\section{Conclusions and proposals}

As already described, the features of higher education in El Salvador represent a barrier to the development of a knowledge-based economy and therefore to reaching satisfactory levels of sustainable human development. In general, El Salvador has a poorly qualified population, which, in particular, is poorly specialized. Furthermore, higher education is characterized by its low quality - outdated methods and syllabuses and poorly qualified and poorly motivated teachers - and its lack of pertinence, reflected in conflicts between education and labour systems with serious consequences for social mobility among young people. In light of this situation, the following 
proposals are aimed at improving university graduates' chances of entering the labour market.

The first proposal concerns improving the education system's pertinence by seeking a balance between the realities of the labour market and the needs of the territory. Better interministerial collaboration within El Salvador's government could help to achieve this goal. Such collaboration would allow the Ministry of Education to adjust the academic courses available to students by using data from the Ministry of Economy and the Ministry of Work and Social Support. The Ministry of Education could thus limit the number of places available for oversubscribed degrees. Participatory Territorial Diagnosis can contribute to meeting this goal. Likewise, fostering publicprivate partnerships can help new graduates to enter the labour market. Internship programmes could and should help this process.

The second proposal consists of introducing a module on education for entrepreneurship, which would be compulsory for all higher education programmes in El Salvador. Such a module could help graduates to enter the labour market, encouraging high-quality and sustainable self-employment, completely consistent with the previous approach, thus stimulating opportunity-driven entrepreneurship and reducing the high level of graduate unemployment. Thus, this module's teaching objectives would be to develop entrepreneurial aptitudes and attitudes, thereby counteracting the current lack of emphasis on fostering entrepreneurial spirit, creativity, and reflection (Sanders et al., 2012). Implementing models based on the development of general and specific characteristics is important to train and educate well-rounded human beings.

This proposal nonetheless has some limitations. Despite the pertinence of the aforementioned proposals, alone they are inadequate to ensure that education trains and educates well-round human beings. The design of an educational system along these lines should cover all stages of education from primary education onwards. These goals cannot be attained by changing higher education only. In addition, as per the McKinsey report entitled How the world's best performing school systems come out on top (Barber \& Mourshed, 2007), the teaching faculty must be capable of achieving these goals. Hence, there must be an emphasis on the selection of teachers with suitable attitudes and aptitudes and on their ongoing training so that they may offer the best education to each student.

Future studies should focus on the issue of training and educating El Salvador's young people as well-rounded human beings and key contributors to El Salvador's development. Likewise, it is important to design new indicators to measure quality, pertinence, and internal institutional processes, particularly regarding how to foster entrepreneurship in El Salvador's higher education system.

\section{References}

Acs, Z. J., \& Amorós, J. E. (2008). Entrepreneurship and competitiveness dynamics in Latin America. Small Business Economics, 31(3), 305-322.

Amorós, J. E., \& Cristi, O. (2008). Longitudinal analysis of entrepreneurship and competitiveness dynamics in Latin America. International Entrepreneurship and Management Journal, 4(4), 381-399. 
Audretsch, D. B. (2007). The Entrepreneurial Society. Oxford, UK: Oxford University Press.

Barber, M., \& Mourshed, M. (2007). How the world's best-performing schools systems come out on top. McKinsey \& Company. Retrieved January 15, 2015, from http://mckinseyonsociety.com/downloads/reports/Education/Worlds_School_Syst ems_Final.pdf

Clark, B. R. (2004). Delineating the character of the entrepreneurial university. Higher Education Policy, 17(4), 355-370.

Dirección Nacional de Educación Superior (2014). Resultados de la información estadística de instituciones de educación superior 2013. San Salvador: Ministerio de Educación de El Salvador.

Levie, J., \& Autio, E. (2008). A theoretical grounding and test of the GEM model. Small business economics, 31(3), 235-263.

Ley de Educación Superior, Decreto 468, Diario Oficial n ${ }^{\circ} 216$ Tomo $^{\circ} 365$. Asamblea Legislativa República de El Salvador, San Salvador, El Salvador, 14 de octubre de 2004.

López-Claros, A., Blanke, J., Drzeniek, M., M1'a, I., \& Zahidi, S. (2005). Underpinning economic growth: Results from the competitiveness indexes. In A. Lopez-Claros, M. Porter \& K. Schwab (Eds.), Global competitiveness report 2005-2006: Policies underpinning rising prosperity (pp. 3-42). New Hampshire: Palgrave Macmillan.

Miles, R., Miles, G., and Snow, C. (2005). Collaborative entrepreneurship. Stanford, CA: Stanford University Press.

Ministerio de Educación (2014). La Educación de El Salvador en cifras 2009-2013. San Salvador: Ministerio de Educación de El Salvador. Gerencia del Sistema de Estadísticas Educativas. Retrieved January 15, 2015, from https://www.mined.gob.sv/estadisticas/Publicacion_Eduacacion_2009-2013.pdf

Ministerio de Educación (2010). Cuentas Nacionales de Inversión en Educación. Indicadores de inversión en el sistema educativo de El Salvador. San Salvador: Ministerio de Educación de El Salvador.

Ministerio de Educación (2009a). Cuentas Nacionales de Educación Versión General. San Salvador: Ministerio de Educación de El Salvador.

Ministerio de Educación (2009b). Cuentas Nacionales de Inversión en Educación (CNIE). Actualización de estimaciones de inversión en el sistema educativo de El Salvador 2008-2009. San Salvador: Ministerio de Educación de El Salvador.

Porter, M., Sachs, J., \& McArthur, J. (2002). Executive summary: Competitiveness and stages of economic development. In M. Porter, J. Sachs, P. K. Cornelius, J. W. McArthur \& K. Schwab (Eds.), The global competitiveness report 2001-2002 (pp. 16-25). New York: Oxford University Press.

Sánchez-Masferrer, M. (2013). Global entrepreneurship monitor: informe nacional El Salvador 2012. GEM Consortium. Retrieved January 15, 2015, from http://www.gemconsortium.org/docs/3121/gem-el-salvador-2012-report

Saunders, R., Rivas, F., Rabossi, M., Ruiz, A. M., Avanzini, D., \& Helwig, J. (2012). El Salvador: Evaluación de la Educación Superior y recomendaciones. USAID. Retrieved January 15, 2015, from http://pdf.usaid.gov/pdf_docs/pa00hx9k.pdf

Schramm, C. J. (2006). The entrepreneurial imperative. New York: Collins. 
SITEAL (2013). Perfil de El Salvador. IIPE UNESCO y OEI. Retrieved January 05, 2015 , from http://www.siteal.iipeoei.org/sites/default/files/perfil_el_salvador_2013_06.pdf

Terjesen, S., \& Amorós, J. E. (2010). Female entrepreneurship in Latin America and the Caribbean: Characteristics, drivers and relationship to economic development. European Journal of Development Research, 22(3), 313-330.

UNDP (2013). Informe sobre Desarrollo Humano El Salvador 2013: Imaginar un nuevo país. Hacerlo posible. San Salvador: United Nations Development Program.

Wennekers, S., Van Wennekers, A., Thurik, R., \& Reynolds, P. (2005). Nascent entrepreneurship and the level of economic development. Small business economics, 24(3), 293-309. 